\section{Social inequality in health among women in Campinas, São Paulo State, Brazil}

\author{
Desigualdades sociais na saúde de mulheres \\ adultas no Município de Campinas, \\ São Paulo, Brasil
}

\footnotetext{
1 Faculdade de Ciências Médicas, Universidade Estadual de Campinas, Campinas, Brasil.

Correspondence C. Senicato Departamento de Saúde Coletiva, Faculdade de Ciências Médicas, Universidade Estadual de Campinas.

Rua Tessália Vieira de Camargo 126, Campinas, SP 13083-887, Brasil. senicato@fcm.unicamp.br
}

\begin{abstract}
The aim of this was study was to assess social inequalities in health status and use of health services according to level of schooling in women. This was a cross-sectional population-based study with a sample of 508 women from 20 to 59 years of age living in Campinas, São Paulo State, Brazil (ISA-Camp 2008). Women with less schooling showed higher prevalence of hypertension, circulatory problems, headache, dizziness, obesity, common mental disorders, worse self-rated health, use of dental prosthesis, and visual impairment, but lower prevalence for use of eyeglasses. There were no differences between the two schooling strata in prevalence of medical visits in the previous two weeks, use of medicines in the three previous days, Pap smear, breast selfexamination, clinical breast examination, hospitalizations and surgeries in the previous year, and rubella vaccination any time in life. The only significant differences were in use of dental services and mammograms. The results show social inequalities in various health indicators and equity in access to various components of the health services.
\end{abstract}

Women's Health; Social Inequity; Health Inequalities
Caroline Senicato 1

Marilisa Berti de Azevedo Barros 1

\section{Introduction}

Women are among the social groups most affected by health inequality, due to their direct experience with discrimination and disadvantages 1 . They constitute the majority of the Brazilian population, participate significantly in the country's workforce (Instituto Brasileiro de Geografia e Estatística. Censo demográfico de 2010. http:// www.ibge.gov.br), and play a central role in the organization and care of the family and home. However, women's living conditions differ profoundly, depending on their socioeconomic status, with a differential impact on their health and disease profile.

Among the 12 diseases investigated in the $\mathrm{Bra}$ zilian National Household Sample Survey (PNAD) for 2008, hypertension, back disease, arthritis/ rheumatism, depression, bronchitis/asthma, heart disease, diabetes, tendinitis/tenosynovitis, chronic kidney failure, and cancer were significantly more prevalent in women ${ }^{2}$. Importantly, health inequalities are seen between groups of women according to different social characteristics, such as schooling ${ }^{3}$, income ${ }^{4}$, occupation 5 , race and ethnicity, and place of residence 2 . Data from the Telephone Survey Surveillance System for Risk and Protective Factors for Chronic Diseases (VIGITEL) showed a higher prevalence of one or more chronic diseases among women with less schooling ${ }^{6}$ and lower prevalence of ar- 
terial hypertension in women with more schooling ${ }^{7}$. In American women, low socioeconomic status was also associated with a worse profile of biomarkers for cardiovascular diseases and diabetes ${ }^{4}$. According to a European study, in all 22 countries studied the mortality rate (except for breast cancer) was higher in the group with less schooling, and in the female population $51 \%$ of deaths from cardiovascular disease occurred among women with the least schooling 8 .

Women use health services more than men, but it has been shown that the women with the highest odds of using health services are those belonging to families with higher income, where the head-of-household has more schooling, and from families headed by men ${ }^{9}$. Social inequalities among women also appear in access to preventive health services. According to a systematic review, access to Pap smears in Brazil was associated with more schooling ${ }^{10}$. Inequality was also found in mammography, where the odds of performing a mammogram increased with per capita family income and schooling, as well as among married women and those with private health insurance 11. Data from the 2008 PNAD confirm the greater utilization of the public Brazilian Unified National Health System (SUS) by population groups with lower income and less schooling and those without private health insurance, thus demonstrating the importance of the public healthcare service for the socially underprivileged population ${ }^{12}$. Guaranteeing access to the health system for all social groups, especially for the most vulnerable, is essential for minimizing social inequalities in health and compensating for initial socioeconomic iniquity 13 .

In the United Nations High-Level Meeting on the Prevention and Control of Non-Communicable Diseases in September 2011, Brazil reaffirmed women's health as a government priority, and thus committed the country to expand access to preventive tests, decrease morbidity and mortality from breast and uterine cervical cancer, and guarantee free access to medicines for hypertension and diabetes, especially for the poorest members of the population, among other objectives 14 .

Considering both the importance of policies for the promotion of women's health and the prevailing inequalities between different social segments of the population, the aim of this study was to determine the magnitude of social iniquity in health and in the use of health services among women 20 to 59 years of age living in the urban area of Campinas, São Paulo State, Brazil, according to social strata defined by level of schooling. The study attempted to evaluate the degree of prevailing social inequality in different health dimensions and provide information for more effective interventions to promote equity.

\section{Methods}

This was a cross-sectional population-based study that used data from the Campinas Municipal Health Survey (ISA-Camp) in 2008, conducted by the Collaborating Center in Health Situation Analysis at the Department of Collective Health, State University in Campinas (Departamento de Saúde Coletiva, Universidade Estadual de Campinas - UNICAMP).

The survey aimed to obtain information on three age brackets: adolescents (10 to 19 years), adults (20 to 59), and elderly (60 years or older). The sample size was defined considering an estimated proportion of 0.50 , with a maximum error of 4 to 5 percentage points, with a $95 \%$ confidence interval $(95 \% \mathrm{CI})$ and a design effect of 2 , resulting in a thousand individuals for each of the three age brackets. Expecting an $80 \%$ response rate, the sample size was corrected to 1,250 individuals in each bracket.

The sampling process in ISA-Camp 2008 involved two stages: census tracts and households. In the first stage, 50 census tracts were selected in the urban area of Campinas with probability proportional to the number of households. Systematic selection was performed, in which the tracts were previously ordered by the percentage of heads-of-families with university degrees. In the second stage, households were selected from the 50 previously selected census tracts. For each age bracket, independent samples of households were selected. Based on the probability of family members from each age bracket living in the household, according to data from the $2000 \mathrm{Na}$ tional Population Census (Instituto Brasileiro de Geografia and Estatística; http://www.ibge. gov.br), 2,150, 700, and 3,900 households were selected, respectively, for interviews with adolescents, adults, and elderly. All household residents belonging to the selected age bracket were interviewed 15 .

The current study only analyzed data on female adults 20 to 59 years of age.

Demographic, socioeconomic, health status, health-related behavior, and health services utilization data were obtained from a previously tested structured questionnaire, applied by trained, supervised interviewers. Interviews were conducted directly with the selected individual.

The target variables in this study were: a) Schooling (used as a proxy for socioeconomic status), defined as years of schooling and categorized as 0 to 8 years versus and 9 years or more; 
b) Demographic and socioeconomic variables: age bracket, self-reported skin color/race, marital status, number of children, religion, paid work, per capita monthly family income (calculated as times the monthly minimum wage), number of household assets (radio, TV, refrigerator, freezer, clothes washer, among others), private health plan, and head-of-family's schooling;

c) Health status and diseases: illness in previous two weeks; diseases (reported as having been diagnosed by a physician or other health professional) according to a checklist: arterial hypertension, diabetes, heart disease, rheumatism/arthritis/ arthrosis, asthma/bronchitis/emphysema, tendinitis/repetitive strain injury (RSI)/work-related musculoskeletal disorders (WRMD), circulatory problem; number of reported chronic diseases among those listed above; health problem: headache/migraine, back pain/back problem, allergy, emotional problem (anxiety/sadness), dizziness/ vertigo, insomnia, and urinary problem; number of self-reported health problems among those listed above; obesity, defined as BMI $\geq 30.0 \mathrm{~kg} / \mathrm{m}^{2}$ and estimated according to self-reported weight and height; common mental disorders (CMD) assessed by the Self-Report Questionnaire (SRQ-20) with the cutoff set at greater than or equal to 8 points 16 , bad/very bad self-rated health; visual impairment, use of eyeglasses and/or contact lenses, use of dental prosthesis, and accident or episode of violence in the previous year;

d) Use of health services: use of health services in the previous two weeks; use of medicines in the previous three days; dental visit, hospitalization, or surgery in the previous year; Pap smear in the previous three years 17; breast self-examination in the previous month; clinical breast examination in the previous year, for women 40 to 59 years of age 18; mammogram in the previous two years for women 50 to 59 years of age 18; and previous rubella vaccination for women 20 to 49 years of age, which covers the childbearing age for susceptibility to congenital rubella syndrome 19 .

The dependent variables in this study were those indicating health conditions and use of health services, and the independent variable was level of schooling (in years). The other demographic and socioeconomic variables were used to describe the social characteristics of the two strata of women defined according to level of schooling.

Associations between the variables were measured by the chi-square test with $5 \%$ significance. Simple and multiple Poisson regression models with robust variance were used to estimate the crude and adjusted prevalence ratios (PR) and their 95\% confidence intervals (95\%CI). Age (continuous) was used as an adjustment variable to control for differences in age structure between the two schooling strata, and the number of non-communicable diseases was used to adjust indicators on use of health services, which is influenced by the patient's illnesses. Statistical analyses were performed with Stata version 11.0, module svy (Stata Corp., College Station, USA) and considered the sample weights and design effect. The research project was approved by the institutional Review Board of the School of Medicine at UNICAMP (Faculdade de Medicina, in an addendum to case no. 079/2007.

\section{Results}

In $19.6 \%$ of the households selected for the sample of adults, it was not possible to enroll the individual, either because the person refused to participate (10.1\%), was not located $(3.7 \%)$, or for some other reason (5.8\%). Of the 1,082 adults located in the household and who were supposed to be interviewed, the refusal rate was $11.5 \%$. The study sample consisted of 508 women ranging from 20 to 59 years of age, $29.8 \%$ of the population of women in the study were 20 to 29 years old, and $19.5 \%$ were in the $50-59$-year bracket. There was a statistically significant difference $(p<0.05)$ between women in the two schooling strata, in terms of the target demographic and socioeconomic variables (Table 1). The group with more schooling showed a higher proportion of young, white, single, and Catholic women and those with no children, higher monthly per capita family income, more household assets, private health insurance, and heads-of-families with more schooling.

As for health status (Table 2), after adjusting for age, women with less schooling reported higher prevalence of hypertension $(\mathrm{PR}=1.58)$, circulatory problems $(\mathrm{PR}=1.92)$, and two or more chronic diseases among the ten studied $(\mathrm{PR}=1.60)$. Women with less schooling also reported higher prevalence of the following: headache $(P R=1.76)$, dizziness $(P R=2.03)$, two or more health problems among the seven studied ( $P R=1.37)$, obesity $(P R=1.49)$, common mental disorders ( $P R=2.10)$, bad or very bad self-rated health $(\mathrm{PR}=2.52)$, visual impairment $(\mathrm{PR}=1.85)$, and use of dental prosthesis $(\mathrm{PR}=4.97)$. Only prevalence of use of eyeglasses or contact lenses $(\mathrm{PR}=0.70)$ was lower among women with 8 years of school or less, as compared to women with more schooling.

Concerning use of health services, women with less schooling showed significantly lower prevalence rates for dental visits in the previous year $(P R=0.64)$ and mammograms $(P R=0.63)$ 
Demographic and socioeconomic characteristics according to level of schooling among women 20 to 59 years of age. ISA-Camp, Campinas, São Paulo State, Brazil, 2008.

\begin{tabular}{|c|c|c|c|c|c|c|c|}
\hline \multirow[t]{3}{*}{ Variables } & \multicolumn{6}{|c|}{ Schooling (years) } & \multirow{3}{*}{$p$-value * } \\
\hline & \multicolumn{2}{|c|}{ Total } & \multicolumn{2}{|c|}{$0-8$} & \multicolumn{2}{|c|}{$\geq 9$} & \\
\hline & $\mathbf{n}$ & $\%$ & $\mathbf{n}$ & $\%$ & $\mathbf{n}$ & $\%$ & \\
\hline Age bracket (years) & & & & & & & $<0.0001$ \\
\hline $20-29$ & 150 & 29.8 & 33 & 15.3 & 117 & 40.4 & \\
\hline $30-39$ & 131 & 26.2 & 58 & 26.9 & 73 & 25.6 & \\
\hline $40-49$ & 126 & 24.5 & 62 & 28.1 & 64 & 21.9 & \\
\hline $50-59$ & 101 & 19.5 & 66 & 29.7 & 35 & 12.1 & \\
\hline Total & 508 & & 219 & & 289 & & \\
\hline Skin color/Race & & & & & & & 0.0093 \\
\hline White & 370 & 73.8 & 145 & 66.5 & 225 & 79.1 & \\
\hline Black or Brown & 135 & 26.2 & 73 & 33.5 & 62 & 20.9 & \\
\hline Marital status & & & & & & & $<0.0001$ \\
\hline Married & 236 & 46.4 & 109 & 49.3 & 127 & 44.2 & \\
\hline Living with partner & 78 & 15.3 & 46 & 21.3 & 32 & 11.0 & \\
\hline Separated/Divorced/Widow & 69 & 13.3 & 41 & 18.8 & 28 & 9.4 & \\
\hline Single & 125 & 25.0 & 23 & 10.6 & 102 & 35.4 & \\
\hline Number of children & & & & & & & $<0.0001$ \\
\hline 0 & 133 & 26.8 & 21 & 9.7 & 112 & 39.1 & \\
\hline 1 & 107 & 21.3 & 39 & 18.1 & 68 & 23.6 & \\
\hline 2 & 137 & 26.8 & 68 & 30.9 & 69 & 23.8 & \\
\hline$\geq 3$ & 131 & 25.1 & 91 & 41.3 & 40 & 13.5 & \\
\hline Religion & & & & & & & 0.0416 \\
\hline Catholic & 251 & 49.6 & 98 & 44.4 & 153 & 53.3 & \\
\hline Protestant & 183 & 35.5 & 95 & 43.4 & 88 & 29.8 & \\
\hline Other/None & 74 & 14.9 & 26 & 12.2 & 48 & 16.9 & \\
\hline Paid work & & & & & & & 0.0003 \\
\hline Yes & 307 & 60.8 & 112 & 51.3 & 195 & 67.7 & \\
\hline No & 201 & 39.2 & 107 & 48.7 & 94 & 32.3 & \\
\hline Monthly per capita family income (times minimum & & & & & & & $<0.0001$ \\
\hline wage) $* \star$ & & & & & & & \\
\hline$<1$ & 218 & 42.1 & 134 & 61.1 & 84 & 28.4 & \\
\hline$\geq 1$ & 290 & 57.9 & 85 & 38.9 & 205 & 71.6 & \\
\hline Number of household assets & & & & & & & $<0.0001$ \\
\hline $1-9$ & 287 & 55.5 & 168 & 76.4 & 119 & 40.4 & \\
\hline$\geq 10$ & 220 & 44.5 & 51 & 23.6 & 169 & 59.6 & \\
\hline Private health insurance & & & & & & & $<0.0001$ \\
\hline Yes & 223 & 45.0 & 47 & 21.6 & 176 & 61.9 & \\
\hline No & 285 & 55.0 & 172 & 78.4 & 113 & 38.1 & \\
\hline Head-of-family's schooling (years) & & & & & & & $<0.0001$ \\
\hline $0-8$ & 264 & 50.7 & 178 & 81.4 & 86 & 28.7 & \\
\hline$\geq 9$ & 243 & 49.3 & 40 & 18.6 & 203 & 71.3 & \\
\hline
\end{tabular}

* Chi-square test;

** Prevailing monthly minimum wage at the time of the study: January-April 2008: $R \$ 415.00$ (exchange rate, April 2008: U\$1.00 = R $\$ 1.69$ ); May 2008 to April 2009: $\mathrm{R} \$ 450.00$ (exchange rate, April 2009: U\$1.00 = R\$2.19). 
Prevalence (\%) and prevalence ratios (PR) for self-reported diseases and health problems according to level of schooling among women 20 to 59 years of age. ISA-Camp, Campinas, São Paulo State, Brazil, 2008.

\begin{tabular}{|c|c|c|c|c|c|c|}
\hline \multirow[t]{3}{*}{ Variables } & \multicolumn{3}{|c|}{ Schooling (years) } & \multirow{3}{*}{$\mathrm{p}$-value * } & \multirow{3}{*}{ Crude PR $(95 \% \mathrm{Cl}) * \star$} & \multirow{3}{*}{ 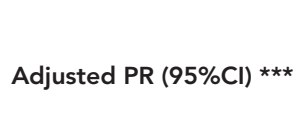 } \\
\hline & Total & & $\geq 9$ & & & \\
\hline & $\%$ & $\%$ & $\%$ & & & \\
\hline Hypertension & 16.5 & 24.8 & 10.6 & $<0.0001$ & $2.34(1.59-3.46)$ & $1.58(1.04-2.42)$ \\
\hline Diabetes & 4.6 & 6.3 & 3.4 & 0.1331 & $1.85(0.81-4.21)$ & $1.11(0.48-2.58)$ \\
\hline Heart disease & 4.2 & 6.2 & 2.7 & 0.0686 & $2.35(0.91-6.10)$ & $1.69(0.65-4.37)$ \\
\hline Rheumatism/Arthritis/Arthrosis & 5.8 & 9.1 & 3.4 & 0.0055 & $2.69(1.32-5.48)$ & $1.33(0.58-3.01)$ \\
\hline Asthma/Bronchitis/Emphysema & 4.1 & 4.6 & 3.8 & 0.6410 & $1.23(0.50-3.04)$ & $0.98(0.39-2.45)$ \\
\hline Tendinitis/RSI/WRMD & 7.5 & 7.3 & 7.6 & 0.9080 & $0.97(0.53-1.76)$ & $0.76(0.42-1.39)$ \\
\hline Circulatory problem & 12.5 & 20.4 & 6.8 & $<0.0001$ & $3.01(1.97-4.60)$ & $1.92(1.20-3.05)$ \\
\hline Prevalence of $\geq 2$ chronic diseases & 17.2 & 26.3 & 10.6 & 0.0001 & $2.48(1.59-3.87)$ & $1.60(0.99-2.57)$ \\
\hline Headache/Migraine & 34.7 & 45.1 & 27.2 & 0.0001 & $1.66(1.30-2.11)$ & $1.76(1.37-2.26)$ \\
\hline Backache/Back problem & 35.1 & 43.8 & 28.8 & 0.0061 & $1.52(1.13-2.05)$ & $1.31(0.97-1.77)$ \\
\hline Allergy & 32.5 & 29.7 & 34.5 & 0.3072 & $0.86(0.64-1.15)$ & $0.86(0.64-1.16)$ \\
\hline Emotional problem (anxiety/sadness) & 25.6 & 31.2 & 21.5 & 0.0263 & $1.45(1.05-2.00)$ & $1.30(0.91-1.85)$ \\
\hline Dizziness/Vertigo & 12.6 & 19.1 & 7.9 & 0.0001 & $2.42(1.56-3.76)$ & $2.03(1.23-3.36)$ \\
\hline Insomnia & 19.9 & 25.1 & 16.1 & 0.0364 & $1.56(1.02-2.37)$ & $1.23(0.76-1.98)$ \\
\hline Urinary problem & 4.8 & 6.7 & 3.5 & 0.1176 & $1.91(0.83-4.40)$ & $1.75(0.72-4.24)$ \\
\hline Prevalence of $\geq 2$ health problems & 46.4 & 56.6 & 39.1 & 0.0006 & $1.45(1.17-1.79)$ & $1.37(1.08-1.73)$ \\
\hline Illness (previous 2 weeks) & 21.9 & 25.6 & 19.2 & 0.1088 & $1.33(0.94-1.90)$ & $1.25(0.85-1.85)$ \\
\hline Obesity (BMI $\left.\geq 30 \mathrm{~kg} / \mathrm{m}^{2}\right)$ & 17.7 & 23.7 & 13.3 & 0.0005 & $1.78(1.29-2.45)$ & $1.49(1.05-2.13)$ \\
\hline CMD (SRQ-20) & 11.9 & 18.4 & 7.2 & 0.0002 & $2.56(1.56-4.21)$ & $2.10(1.25-3.53)$ \\
\hline Bad/very bad self-rated health & 7.5 & 12.3 & 4.1 & 0.0049 & $3.01(1.35-6.69)$ & $2.52(1.04-6.09)$ \\
\hline Visual impairment & 13.6 & 19.6 & 9.2 & 0.0028 & $2.12(1.27-3.53)$ & $1.85(1.09-3.15)$ \\
\hline Eyeglasses and/or contact lenses & 44.4 & 42.4 & 45.8 & 0.4281 & $0.93(0.76-1.12)$ & $0.70(0.58-0.84)$ \\
\hline Dental prosthesis & 14.2 & 28.8 & 3.6 & $<0.0001$ & $7.98(3.90-16.32)$ & $4.97(2.30-10.78)$ \\
\hline Accident (previous year) & 5.5 & 7.2 & 4.3 & 0.2762 & $1.66(0.65-4.23)$ & $1.65(0.65-4.21)$ \\
\hline Violence (previous year) & 5.5 & 6.0 & 5.2 & 0.6247 & $1.16(0.62-2.17)$ & $1.17(0.58-2.36)$ \\
\hline
\end{tabular}

BMI: body mass index; CMD: common mental disorders; RSI: repetitive strain injury; SRQ-20: Self-Report Questionnaire; WRMD: work-related musculoskeletal; 95\% Cl: $95 \%$ confidence interval.

* Chi-square test;

** Simple Poisson regression model. Reference category: $\geq 9$ years of schooling;

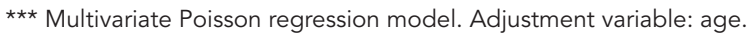

Note: Statistically significant values in boldface. Confidence interval does not include 1.

in the previous two years (Table 3). There were no statistically significant differences between the two levels of schooling in relation to use of health services in the previous two weeks, use of medicines in the previous three days, or hospitalization and surgeries in the previous year, even when the analysis was adjusted for number of self-reported diseases. Neither were there any differences in monthly breast self-examination, clinical breast examination in the previous year, Pap smear in the previous three years, or previous rubella vaccination.

\section{Discussion}

The current study's most significant findings were the striking socioeconomic inequality between the two schooling strata in this population of women, expressed as disparities in various health problems, and the absence of inequalities in relation to various indicators for use of health services.

The strong association between socioeconomic and demographic variables and schooling revealed two distinct social segments: as expected, women with less schooling showed 
Prevalence (\%) and prevalence ratios (PR) for use of health services according to level of schooling in women 20 to 59 years of age. ISA-Camp, Campinas, São Paulo State, Brazil, 2008

\begin{tabular}{|c|c|c|c|c|c|c|}
\hline \multirow[t]{3}{*}{ Variables } & \multicolumn{3}{|c|}{ Schooling (years) } & \multirow[t]{3}{*}{ p-value * } & \multirow[t]{3}{*}{ Crude PR $(95 \% \mathrm{Cl}) * \star$} & \multirow{3}{*}{$\begin{array}{l}\text { Adjusted PR } \\
(95 \% \mathrm{PR}) \star \star \star\end{array}$} \\
\hline & Total & $0-8$ & $\geq 9$ & & & \\
\hline & $\%$ & $\%$ & $\%$ & & & \\
\hline Use of health service (previous 2 weeks) & 22.2 & 22.1 & 22.4 & 0.9351 & $0.99(0.71-1.38)$ & $0.84(0.59-1.20) \#$ \\
\hline Use of medicines (previous 3 days) & 64.1 & 66.7 & 62.2 & 0.3120 & $1.07(0.93-1.23)$ & $0.96(0.85-1.09) \#$ \\
\hline Dental visit (previous year) & 59.7 & 46.4 & 69.4 & 0.0001 & $0.67(0.56-0.79)$ & $0.64(0.54-0.77)$ \\
\hline Hospitalization (previous year) & 11.1 & 12.1 & 10.3 & 0.4607 & $1.17(0.76-1.80)$ & $1.18(0.74-1.88) \#$ \\
\hline Surgery (previous year) & 12.8 & 10.5 & 14.7 & 0.1270 & $0.71(0.46-1.11)$ & $0.76(0.46-1.25) \#$ \\
\hline Pap smear (previous 3 years) & 86.2 & 83.8 & 87.9 & 0.2630 & $0.95(0.87-1.04)$ & $0.94(0.86-1.02)$ \\
\hline Breast self-examination (previous month) & 38.2 & 38.3 & 38.1 & 0.9621 & $1.01(0.78-1.29)$ & $0.87(0.68-1.12)$ \\
\hline Clinical breast examination (previous year) [40-59 years] & 57.5 & 50.4 & 66.1 & 0.0167 & $0.76(0.61-0.95)$ & $0.80(0.63-1.02)$ \\
\hline Mammogram (previous 2 years) [50-59 years] & 62.1 & 51.3 & 80.8 & 0.0013 & $0.64(0.50-0.81)$ & $0.63(0.50-0.80)$ \\
\hline Previous rubella vaccination [20-49 years] & 86.2 & 84.2 & 87.3 & 0.4868 & $0.96(0.86-1.07)$ & $0.86(0.67-1.11)$ \\
\hline
\end{tabular}

* Chi-square test;

** Simple Poisson regression model. Reference category: $\geq 9$ years of schooling;

*** Multiple Poisson regression model. Adjustment variable: age;

\# Adjusted for age and number of chronic non-communicable diseases.

Note: Statistically significant values in boldface. Confidence interval does not include 1.

worse living conditions. Schooling is one of the most widely used indicators for analyzing social inequalities in health 3,8 and is known to continue to impact the social class dimension 20 . The study's reference was the theoretical model on social determinants of health by Solar \& Irwin 21 . According to this model, education (related to the political and socioeconomic context) is among the structural determinants of iniquities in health, together with income and occupation. Schooling influences the material circumstances of life (living conditions, work, food availability, etc.), behavioral, biological, and psychosocial factors that generate impact on equity in health, well-being, and use of health services, just as the prevalence of diseases also impacts the use of health services. As a social determinant, education is related to the individual's position in society, social stratification, and the underlying causes of health iniquities 22 . The historical context in which women's schooling has occurred (marked by gender, socioeconomic, and power inequalities) continues to be reflected in their current living conditions and labor market position and earnings. Although the schooling variable does not capture all the effect of socioeconomic status on health, it is easier to obtain than other socioeconomic indicators, so it is widely used, allowing greater comparability and good stability (since, for a significant portion of the population, it is basically complete by late adolescence). There were proportionally more young women in the stratum with higher schooling, a result of increasing access to the Brazilian educational system that has occurred progressively in the younger generations. The selected cutoff point considered the level of schooling in the target population and the available sample size, which was satisfactory for the analyses in each category. As shown in Table 1, the indicator used in this study was able to discriminate between the two social strata.

The current study found a higher age-adjusted prevalence ratio for two or more chronic diseases in the group with less schooling. Data from the PNAD survey in 2003 and 2008 and the VIGITEL survey in 2006 also showed the strong influence of schooling on the prevalence of noncommunicable diseases 2,6. Studies in other countries have also consistently found health inequality in the prevalence of non-communicable diseases 3,23 .

In this study, hypertension was 1.58 times more prevalent among women with less schooling, corroborating other studies focusing on women in Brazil 7 and elsewhere 4,24 .

Women with less schooling also showed a twofold higher prevalence of circulatory problems, defined in this study as varicose veins or stroke. Social inequalities in the prevalence of 
circulatory problems have been reported by other authors 4 . In Brazil, in 2008, a downward prevalence was observed in heart disease among strata with more schooling ${ }^{2}$.

As for women's self-reported health problems, less schooling was associated with higher prevalence of frequent headache or migraine. In a population-based study in Denmark, increased risk of migraine in women was associated with less schooling, marital status (married), unemployment, heavy physical workload, obesity, and smoking 25 . Data from a prospective cohort study of 22,718 adults showed that schooling, income, and occupation were associated with differences in frequent and chronic headache 26 . According to some authors, the association between socioeconomic status and headache can have many causes, such as stress and unhealthy lifestyle, which are more prevalent in economically underprivileged groups 25 . However, various studies in Brazil 27 and elsewhere 28 failed to find an association between migraine and socioeconomic status, thus highlighting the need for further research on the theme.

Dizziness was approximately twice as prevalent in women with less schooling. A study in Germany in individuals 18 years or older found an association between schooling and vertigo in both the univariate and adjusted analyses, which persisted after adjusting for age and gender 29 . In a study of migraine patients, dizziness and vertigo were frequent symptoms, more intense and lasting longer on days in which headache was present 30 . The current study found a statistically significant association between headache/ migraine and dizziness/vertigo $(\mathrm{p}<0.01)$ (data not shown).

Social inequalities in prevalence of obesity in women have been reported consistently by studies in Brazil 31 and elsewhere 32 . In the current study, obesity was $50 \%$ more prevalent among women with less schooling, reaching $23.7 \%$ of this group. In a study using data from the 2006 VIGITEL survey, $11 \%$ of women 18 years or older presented obesity, which was 1.96 times more prevalent among women with four years of schooling or less (as compared to 12 years or more) ${ }^{31}$. A cross-sectional study in 19 European countries found an inverse gradient between schooling and overweight/obesity among women 25 to 44 years of age 32 . Low socioeconomic status not only limited access to more expensive food with higher nutritional value but also influenced access to information on health and the adoption of healthy behaviors, including the choice of healthy diet 33 .

The current study showed 2.10 times more CMD (common mental disorders) among wom- en with less schooling. An inverse association between schooling and $\mathrm{CMD}$ has been reported in other Brazilian studies 34,35. Even in more developed countries, schooling is a socioeconomic variable strongly associated with CMD 36 . According to some authors, by providing better possibilities for improving living conditions, schooling influences attitudes and behaviors that produce positive effects on mental health 37 .

The prevalence of bad or very bad self-rated health in the female population was 2.52 times higher among women with less schooling. Data from the VIGITEL survey in the population 18 years or older showed 3.11 times higher prevalence of bad self-rated health in women with 8 years of schooling or less as compared to those with 12 years or more; in addition, the strong effect of schooling was not eliminated when healthrelated behaviors were included in the regression model 38. This result indicates that health behaviors do not entirely explain the socioeconomic differences in self-rated health, as proposed in the theory based on behaviors/lifestyle, which emphasizes the role of individual choices. However, behaviors represent relevant mediators of the effect of schooling on self-rated health. Inadequate health behaviors are the principal avoidable risk factors for non-communicable diseases and are more prevalent in social strata with less schooling ${ }^{38}$. Other studies in Brazil and elsewhere confirm the existence of social inequality in self-rated health among women 6,39.

This study also showed inequality in the frequency of visual impairment, defined in this study as difficulty seeing or blindness in one or both eyes. A study in four regions of the State of São Paulo showed higher prevalence of visual impairment among individuals whose head-offamily had less schooling 40. A relevant finding for Campinas was that although visual impairment was 1.85 times more prevalent among women with less schooling, they were less likely to wear eyeglasses and/or contact lenses ( $\mathrm{PR}=$ 0.70 ). Considering that only $4.7 \%$ of visual impairments involve blindness in one eye (data not shown), most visual impairments could be entirely or partially corrected by eyeglasses or lenses. These data demonstrate the need to expand access to ophthalmology services for socially vulnerable groups.

Differences in health conditions between women from different social strata in Campinas reflect the effect of schooling on the unequal distribution of living conditions that differentially expose groups in the female population to situations involving greater vulnerability to health harms. Education, as a social determinant, is related to the conditions in which persons are 
born, live, grow, work, and age, which account for most of the disease burden 22 .

One of this study's most relevant findings was the absence of inequality between the two schooling strata in terms of access to most of the health services analyzed here. No statistically significant differences were found in: use of health services in the previous two weeks, medicines in the previous three days, and hospitalization or surgery in the previous year, even after adjusting for the number of reported diseases. Prevalence of Pap smear according to the recommended schedule, monthly breast self-examination, clinical breast examination in the previous year, and previous rubella vaccination also showed no differences between the two social strata. These data for Campinas, differ from findings in other Brazilian studies, frequently showing inequality in access to health services. Although social inequalities in access to use of health services were attenuated somewhat between 2003 and 2008 according to the respective PNAD surveys, social conditions continue to heavily influence the use of health services in the Brazilian context 12 . In Brazil, it has been demonstrated that the odds of using health services are higher among individuals with 9 years of schooling or more as compared to those with four years or less 41 . However, the various studies have used different numbers of social strata and different cutoff points.

This study in Campinas, found a significant inequality in access to dental services, corroborating other Brazilian studies 42,43. However, women with less schooling were much more likely to use dental prostheses, as compared to women with more schooling. The inference is that the former lacked sufficient access to preventive and restorative dental service in order to avoid tooth loss, but that they did subsequently have access to the use of dental prostheses. The study did not delve more deeply into questions related to dental prostheses, such as type, site, and the period of life in which the treatment occurred, so it was not possible to conclude whether such access was through the public Unified National Health System, private health plans, or out-ofpocket. Social inequalities in personal hygiene and the search for and use of dental services and difficulty in access to restorative treatment in the public healthcare system could partially explain tooth loss in the lower-income population 44 .

Equitable access to Pap smears as shown in this study has not been seen in other studies in Brazil 10, just as it was not a few years ago in Campinas. Data from 2001 in the city showed that the test was significantly less frequent in women with 4 years of schooling or less and among black or brown women 45 . According to the current study, access to Pap smears has improved, and the public SUS, as structured in Campinas, has now provided equitable access to the test, given that $55 \%$ of women in Campinas depend on the public system.

Unlike Pap smears, there is still important inequality in access to mammograms, as shown already in 2001 46. The supply of mammograms for the lower-income population is still insufficient, despite an increase in the percentage of women that have this test in Campinas. Other studies have confirmed the direct relationship between this test and socioeconomic status in Brazil 11. The lack of equipment and trained human resources are possible factors that hinder equity in access to mammograms in Campinas. The persistence of this inequality in access to mammograms requires urgent measures by health services, since breast cancer is the leading cause of death from malignant tumors among women in Campinas 47.

Some limitations in the current study result from the cross-sectional design, which does not allow causal inferences; although the total number of women interviewed was adequate for estimating most of the prevalence rates, it was insufficient for some less frequent diseases and events. The use of self-reported information is also a limitation. Some chronic diseases can be underestimated, since the disease is only recognized after a diagnosis is performed by a health professional. The magnitude of differences between disease prevalence rates in the schooling strata tends to be underestimated due to the more limited access to medical and diagnostic services by individuals with less schooling, meaning that they are more likely to be unaware of the fact that they have certain diseases. The validity of self-reported information on chronic disease depends on the given disease, comorbidities, and the respondent's sociodemographic characteristics 48 . Still, the use of a checklist 49 and a face-to-face interview 50 , as in the current study, allows establishing direct contact between the interviewer and interviewee, thus fostering better interaction and on-site verification of the latter's living conditions, thus contributing to the validity of the resulting information. Another limitation was that the sample size did not allow working with a larger number of schooling strata, which would have permitted detecting gradients between the various strata. Although the sample size was calculated for adults, and this study only included adult women, we obtained a design effect (deff), which is a parameter that signals the precision of the estimates obtained from a complex sampling as compared to that of a simple random sample, close to 1.2 for the tests of association 
between level of schooling and various variables. This means that for a prevalence of 0.50 in the stratum of women with more schooling, the actual samples of 242 and 184 would be sufficient to detect (with a power of at least $80 \%$ and $5 \%$ type-I error), significant differences of 1 for PR less than 0.72 and greater than 1.28 . Therefore, the complex design effect did not compromise the precision of the estimates in this subgroup of women for the majority of the tests. However, one can assume that for some of the tests, with PR from 0.72 to 1.28 , the study power was insufficient to identify differences as significant 51 . The study's thematic scope allows analyzing social inequalities in diverse health aspects, besides monitoring health iniquities, which is essential for supporting and evaluating public health policies 52 .

To reduce social inequalities in health, among other interventions, it is necessary to expand the coverage and quality of health services, which can improve the diagnosis, control, and treatment of diseases 2 . The equity in many components of the health services in Campinas demonstrates the potential of the SUS to minimize initial social inequalities, and the access to Pap smears proves the capacity to improve access. Meanwhile, without overlooking other government sectors, the differences identified in the health and disease of the Brazilian female population show the need for the SUS to prioritize effective actions in health promotion and equity, capable of remediating the inequalities in the risks of falling ill and dying.

The diversity in Brazil in the structuring and advances in organization of the SUS highlight the importance of local studies analyzing the situation with health conditions and access to health services. To the extent that this study provides local data on women's health, it can contribute to specific public policies, since decentralization of the SUS fosters measures that meet the specificities, especially considering the more vulnerable social groups.

\section{Resumo}

Objetivou-se avaliar as desigualdades sociais no estado de saúde e uso de serviços de saúde segundo o nível de escolaridade entre mulheres adultas. Trata-se de um estudo transversal de base populacional com amostra de 508 mulheres de 20 a 59 anos, residentes em Campinas, São Paulo, Brasil (ISA-Camp 2008). Mulheres com menor escolaridade apresentam maior prevalência de hipertensão, problemas circulatórios, dor de cabeça, tontura, obesidade, transtorno mental comum, pior saúde autorreferida, uso de prótese dentária e deficiência visual, mas menor prevalência de uso de óculos. Não houve diferença entre os dois segmentos na prevalência de consultas nas duas últimas semanas, uso de medicamentos nos últimos três dias, exame de Papanicolaou, autoexame das mamas, exame clínico das mamas, hospitalizações e cirurgias no último ano e vacinação contra rubéola na vida. Diferenças significativas foram apenas em relação ao serviço odontológico e à mamografia. Há presença de desigualdades sociais em diversos indicadores de saúde e de equidade no acesso a vários componentes dos serviços de saúde.

Saúde da Mulher; Iniquidade Social; Desigualdades em Saúde 


\section{Contributors}

C. Senicato prepared the proposal for the article and conducted the literature search, data analysis, and writing of the article. M. B. A. Barros supervised the proposal, data analysis, and writing of the article.

\section{Acknowledgments}

The authors wish to thank the FAPESP (grant no. 2010/04768-2) for the Master's scholarship for C. Senicato, the CNPq (grant no. 409747/2006-8) for funding the research and for the scientific productivity grant for M. B. A. Barros, and the Brazilian Ministry of Health and Campinas Health Secretariat for the financial support to conduct the survey (UNICAMP/FUNCAMP/SMS, grant no. 4300).

\section{References}

1. Braveman P. Health disparities and health equity: concepts and measurement. Annu Rev Public Health 2006; 27:167-94.

2. Barros MBA, Francisco PMSB, Zanchetta LM, César CLG. Tendências das desigualdades sociais e demográficas na prevalência de doenças crônicas no Brasil, PNAD: 2003-2008. Ciênc Saúde Coletiva 2011; 16:3755-68.

3. Braveman P, Cubbin C, Egerter S, Williams DR, Pamuk E. Socioeconomic disparities in health in the United States: what the patterns tell us. Am J Public Health 2010; 100 Suppl 1:S186-96.

4. Kavanagh A, Bentley RJ, Turrell G, Shaw J, Dunstan D, Subramanian SV. Socioeconomic position, gender, health behaviours and biomarkers of cardiovascular disease and diabetes. Soc Sci Med 2010; 71:1150-60.

5. Artazcoz L, Cortès I, Borrell C, Escribà-Agüir V, Cascant L. Social inequalities in the association between partner/marital status and health among workers in Spain. Soc Sci Med 2011; 72:600-7.

6. Barreto SM, Figueiredo RC. Doença crônica, auto-avaliação de saúde e comportamento de risco: diferença de gênero. Rev Saúde Pública 2009; 43 Suppl 2:38-47.

7. Ferreira SRG, Moura EC, Malta DC, Sarno F. Frequência de hipertensão arterial e fatores associados: Brasil, 2006. Rev Saúde Pública 2009; 43 Suppl 2:98-106.
8. Mackenbach JP, Stirbu I, Roskam AJ, Schaap MM, Menvielle G, Leinsalu M, et al. Socioeconomic inequalities in health in 22 European countries. N Engl J Med 2008; 358:2468-81.

9. Travassos C, Viacava F, Pinheiro R, Brito A. Utilização dos serviços de saúde no Brasil: gênero, características familiares e condição social. Rev Panam Salud Pública 2002; 11:365-73.

10. Martins LPL, Thuler LCS, Valente JG. Cobertura do exame de Papanicolaou no Brasil e seus fatores determinantes: uma revisão sistemática da literatura. Rev Bras Ginecol Obstet 2005; 27:485-92.

11. Oliveira EXG, Pinheiro RS, Melo ECP, Carvalho MS. Condicionantes socioeconômicos e geográficos do acesso à mamografia no Brasil, 2003-2008. Ciênc Saúde Coletiva 2011; 16:3649-64.

12. Silva ZP, Ribeiro MCSA, Barata RB, Almeida MF. Perfil sociodemográfico e padrão de utilização dos serviços de saúde do Sistema Único de Saúde (SUS), 2003-2008. Ciênc Saúde Coletiva 2011; 16:3807-16.

13. Barata RB. Como e por que as desigualdades sociais fazem mal à saúde. Rio de Janeiro: Editora Fiocruz; 2009. (Temas em Saúde).

14. Ministério da Saúde. Plano de ações estratégicas para o enfrentamento das doenças crônicas nãotransmissíveis (DCNT) no Brasil 2011-2022. Versão preliminar. Brasília: Ministério da Saúde; 2011. 
15. Alves MCGP. ISA-Campinas 2008/09: plano de amostragem. http://www.fcm.unicamp.br/cen tros/ccas/arquivos/plano_de_amostragem.pdf (accessed on 02/Nov/2011).

16. Mari JJ, Williams P. A validity study of a psychiatric screening questionnaire (SRQ-20) in primary care in the city of Sao Paulo. Br J Psychiatry 1986; 148:23-6.

17. Instituto Nacional de Câncer. Plano de ação para redução da incidência e mortalidade por câncer do colo do útero: Programa Nacional de Controle do Câncer do Colo do Útero. Rio de Janeiro: Instituto Nacional de Câncer; 2010.

18. Instituto Nacional de Câncer. Controle do câncer de mama. Brasília: Ministério da Saúde; 2004.

19. Departamento de Vigilância Epidemiológica, Secretaria de Vigilância em Saúde, Ministério da Saúde. Plano de ação: campanha nacional de vacinação para eliminação da rubéola no Brasil. Brasília: Ministério da Saúde; 2008.

20. Ferraro AR. Escolarização no Brasil: articulando as perspectivas de gênero, raça e classe social. Educação e Pesquisa 2010; 36:505-26.

21. Solar O, Irwin A. A conceptual framework for action on the social determinants of health. Geneva: World Health Organization; 2010. (Discussion Paper Series on Social Determinants of Health, 2).

22. Organização Mundial da Saúde. Diminuindo diferenças: a prática das políticas sobre determinantes sociais da saúde: documento de discussão. Rio de Janeiro: Organização Mundial da Saúde; 2011.

23. Braveman PA, Egerter SA, Mockenhaupt RE. Broadening the focus: the need to address the social determinants of health. Am J Prev Med 2011; 40(1 Suppl 1):S4-18.

24. Duda RB, Kim MP, Darko R, Adanu RMK, Seffah J, Anarfi JK, et al. Results of the Women's Health Study of Accra: assessment of blood pressure in urban women. Int J Cardiol 2007; 117:115-22.

25. Le H, Tfelt-Hansen P, Skytthe A, Kyvik KO, Olesen J. Association between migraine, lifestyle and socioeconomic factors: a population-based crosssectional study. J Headache Pain 2011; 12:157-72.

26. Hagen K, Vatten L, Stovner LJ, Zwart JA, Krokstad S, Bovim G. Low socio-economic status is associated with increased risk of frequent headache: a prospective study of 22,718 adults in Norway. Cephalalgia 2002; 22:672-9.

27. Pahim LS, Menezes AMB, Lima R. Prevalência e fatores associados à enxaqueca na população adulta de Pelotas, RS. Rev Saúde Pública 2006; 40:692-8.

28. Sabia JJ, Rees DI. Individual heterogeneity and reverse causality in the relationship between migraine headache and educational attainment. Econ Educ Rev 2011; 30:913-23.

29. Neuhauser HK, Brevern M, Radtke A, Lezius F, Feldmann M, Ziese T, et al. Epidemiology of vestibular vertigo: a neurologic survey of general population. Neurology 2005; 65:894-904.

30. Salhofer S, Lieba-Samal D, Freydl E, Bartl S, Wiest G, Wöber C. Migraine and vertigo: a prospective diary study. Cephalgia 2010; 30:821-8.

31. Gigante DP, Moura, EC, Sardinha, LMV. Prevalência de excesso de peso e obesidade e fatores associados, Brasil, 2006. Rev Saúde Pública 2009; 43 Suppl 2:83-9.
32. Roskam AJR, Kunst AE, Van Oyen H, Demarest S, Klumbiene J, Regidor E, et al. Comparative appraisal of educational inequalities in overweight and obesity among adults in 19 European countries. Int J Epidemiol 2010; 39:392-404.

33. Monteiro CA, Wolney LC. A tendência secular da obesidade segundo estratos sociais: Nordeste e Sudeste do Brasil, 1975-1989-1997. Arq Bras Endocrinol Metab 1999; 43:186-94.

34. Araújo TM, Pinho PS, Almeida MMG. Prevalência de transtornos mentais comuns em mulheres e sua relação com as características sociodemográficas e o trabalho doméstico. Rev Bras Saude Matern Infant 2005; 5:337-48.

35. Marín-León L, Oliveira HB, Barros MBA, Dalgalarrondo P, Botega NJ. Social inequality and common mental disorders. Rev Bras Psiquiatr 2007; 29:250-3.

36. Lund C, Breen A, Flisher AJ, Kakuma R, Corrigall J, Joska JA, et al. Poverty and common mental disorders in low and middle income countries: a systematic review. Soc Sci Med 2010; 71:517-28.

37. Brown GW, Harris T. Social origins of depression: a study of psychiatric disorder in women. London: Tavistock; 1978.

38. Barros MBA, Zanchetta LM, Moura EC, Malta DC. Auto-avaliação da saúde e fatores associados, Brasil, 2006. Rev Saúde Pública 2009; 43 Suppl 2: 27-37.

39. White HL, Matheson FI, Moineddin R, Dunn JR, Glazier RH. Neighbourhood deprivation and regional inequalities in self-reported health among Canadians: Are we equally at risk? Health Place 2011; 17:361-9.

40. Castro SS, César CLG, Carandina L, Barros MBA, Alves MCGP, Goldbaum M. Deficiência visual, auditiva e física: prevalência e fatores associados em estudo de base populacional. Cad Saúde Pública 2008; 24:1773-82.

41. Travassos C, Oliveira EXG, Viacava F. Desigualdades geográficas e sociais no acesso aos serviços de saúde no Brasil: 1998 e 2003. Ciênc Saúde Coletiva 2006; 11:975-86.

42. Barros AJD, Bertoldi AD. Desigualdades na utilização e no acesso a serviços odontológicos: uma avaliação em nível nacional. Ciênc Saúde Coletiva 2002; 7:709-17.

43. Pinheiro RS, Torres TZG. Uso de serviços odontológicos entre os Estados do Brasil. Ciênc Saúde Coletiva 2006; 11:999-1010.

44. Chavesa SCL, Vieira-da-Silva LM. Inequalities in oral health practices and social space: an exploratory qualitative study. Health Policy 2008; 86: 119-28.

45. Amorim VMSL, Barros MBA, César CLG, Carandina $\mathrm{L}$, Goldbaum M. Fatores associados à não realização do exame de Papanicolaou: um estudo de base populacional no Município de Campinas, São Paulo, Brasil. Cad Saúde Pública 2006; 22:2329-38.

46. Amorim VMSL, Barros MBA, César CLG, Carandina L, Goldbaum M. Fatores associados a não realização da mamografia e do exame clínico das mamas: um estudo de base populacional em Campinas, São Paulo, Brasil. Cad Saúde Pública 2008; 24:2623-32. 
47. Barros MBA, Marin-León L, Belon AP, Almeida SM, Restitutti MC, Marques TG. Mortalidade infantil. Campinas: Departamento de Medicina Preventiva, Faculdade de Ciências Médicas, Universidade Estadual de Campinas/Secretaria Municipal de Saúde; 2010.

48. Okura Y, Urban LH, Mahoney DW, Jacobsen SJ, Rodeheffer RJ. Agreement between self-report questionnaires and medical record data was substantial for diabetes, hypertension, myocardial infarction and stroke but not for heart failure. J Clin Epidemiol 2004; 57:1096-103.

49. Knight M, Stewart-Brown S, Fletcher L. Estimating health needs: the impact of a checklist of conditions and quality of life measurement on health information derived from community surveys. J Public Health Med 2001; 23:179-86.
50. Bergmann MM, Jacobs EJ, Hoffmann K, Boeing H. Agreement of self-reported medical history: comparison of an in-person interview with a selfadministered questionnaire. Eur J Epidemiol 2004; 19:411-6.

51. Sousa MH, Silva NN. Estimativas obtidas de um levantamento complexo. Rev Saúde Pública 2003; 37:662-70.

52. Barros MBA. Inquéritos domiciliares de saúde: potencialidades e desafios. Rev Bras Epidemiol 2008; 11:6-19.

Submitted on 24/Nov/2011

Final version resubmitted on 03/Apr/2012

Approved on 17/Apr/2012 